\title{
USING THE MOBILE PHONE AT WORK: A PERSPECTIVE ON THE BUSINESS NECESSITY AND THE INTERNAL REGULATION
}

\author{
Ștefan Andrei NEȘTIAN ${ }^{a *}$, Silviu Mihail TIȚ $\breve{A}^{b}$, Elena-Sabina TURNEA $^{c}$ \\ a, ${ }^{b},{ }^{c}$ Alexandru Ioan Cuza University of Iași, Romania
}

DOI: $10.24818 / \mathrm{IMC} / 2020 / 04.08$

\begin{abstract}
Using mobile phones at work is no more an option, it becomes a daily habit. Restricted or not, companies should pay attention to the use of mobile devices at work, as long as it can influence the results obtained by the employees. But what connections are between the business necessity for using the mobile phone in working tasks and the internal regulation within organizations? This is the main question of the current paper. Based on a survey on Romanian employees, we have found that the employees perceive a permissive environment created by the managers about the use of mobile phones at work. This finding is supported by the weak or very weak positive correlations between variables describing the business necessity for using the mobile phone at work and the existence of an internal regulation about it. The results of this study can impact managerial decisions, companies’ policies and general work regulations.
\end{abstract}

KEYWORDS: business necessity, employees, internal regulation, mobile phone, type of work.

\section{INTRODUCTION}

Nowadays, mobile phones are multi tasking tools used for personal purposes or at work, with different functions for: social media, communication (through voice calls and text messages), searching information on the Internet, games, and so on. There is no longer a secret that mobile devices are currently replacing computers in order "to call, text, send e-mails, run video conferences, do micro-blogging, interact on social-networks, surf the Internet, watch and share videos and pictures, play video games, and utilize a tremendous array of software-driven applications” (Nestian et al., 2020, p. 2). Moreover, mobile phones become for at least 25\% of teenagers an addiction, since within 5 minutes of waking up, they have reached for a smartphone or other electric device (Colbert et al., 2016).

There are studies which demonstrate that the dependency on mobile phones at work can lead to stress and anxiety, if the mobile phones are not used during work program ( $\mathrm{Li}$ and $\mathrm{Lin}, 2019)$. The mobile devices dependency can be defined as the individuals' reliance on these devices to fulfil different personal/professional goals ( $\mathrm{Li}$ and $\mathrm{Lin}, 2019$ ). For example, there is a tendency among Chinese workers to use every day the mobile phone at work (for work tasks), and thus, to be dependent of this technology ( $\mathrm{Li}$ and Lin, 2019). We have to admit that goal oriented people and media providers are two of the factors that strongly influence this dependency on mobile phones at work (Billieux, et al., 2007; Billieux, et al., 2008). Other studies rely on the aspects of poverty reduction, healthcare, communication services at affordable costs and improving literacy when it comes to discuss about the benefits of using mobile phones at work (Londhe et al., 2014).

According to National Labour Relations Board, the main rules for Social Media Policy applied to all associates who work for an employer, or one of its subsidiary companies in the United States,

\footnotetext{
* Corresponding author. E-mail address: nestian@uaic.ro
} 
are (National Labor Relations Board, 2020): i) Be respectful, always be fair and courteous to fellow associates, customers, members, suppliers or people who work on behalf of employer; ii) Be honest and accurate, make sure you are always honest and accurate when posting information or news, and if you make a mistake, correct it quickly; iii) Post only appropriate and respectful content: maintain the confidentiality, respect financial disclosure laws, do not create a link from your blog, express only your personal opinions. In the same document, National Labour Relations Board presents some rules for using social media during work time: "Refrain from using social media while on work time or on equipment we provide, unless it is work-related as authorized by your manager or consistent with the Company Equipment Policy. Do not use employer e-mail addresses to register on social networks, blogs or other online tools utilized for personal use”.

The relevant analysis in the NLRB memo states: “This company's rule states that, because cell phones can present a distraction in the workplace, resulting in lost time and productivity, personal cell phones may be used for work-related or critical, quality of life activities only. It defines quality of life activities as including communicating with service or health professionals who cannot be reached during a break or after business hours. The rule further states that the cellular functions, such as text messaging and digital photography, are not to be used during working hours" (The National Law Review, accessed on 18 February, 2020).

Starting with the case from 2007, when a Romanian engineer, Bogdan Barbulescu, was fired by his employer for using a Yahoo Messenger account for personal purposes, some voices approved that challenges of workplace surveillance become more apparent, and it is clear that the patchwork legislation does not adequately meet the needs of European workers who do not want to completely forgot their privacy at work (Stevens \& Bronowicka, 2016). In this case, ILO (International Labour Organisation) offered general principles with respect to the protection of workers' personal data and how it ought to be collected, secured, stored, used, and communicated (Stevens \& Bronowicka, 2016). Two decades later, the EU directives apply more specifically to the collecting, storing and processing of personal data about employees, rather than the act of workplace surveillance. However, as the Article 29 Working Party suggests, rules about workers' data, can be extended to their electronic communication: "Any collection, use or storage of information about workers by electronic means will almost certainly fall within the scope of the data protection legislation. This is also the case of the monitoring of workers' e-mail or Internet access by the employer" (European Commission, 2017).

Using of mobile phones can make employees happier, not through the simple fact that this device is owned by them, but through the fact that it has various functions (other than the simple voice calls), such as music and radio services (Londhe et al., 2014). Also, this device reduces the domestic fights and gives a positive attitude and wellbeing (Londhe et al., 2014). Through the fact that the mobile devices contribute to social networks, it seems that they are classified as a disruptive technology (Londhe et al., 2014).

At the same time, rules help people because "working on a busy jobsite or operating tools and heavy machinery requires your full concentration. Inattention or distraction can result in injury to yourself, injury to others, damage to property, or even death. If you're looking at your emails or having a phone conversation, your mind is on something other than your work or your safety. You may even find yourself removing your safety glasses, gloves, hearing protection, or hard hat in order to use your device” (IHSA.ca Magazine, 2020).

Bring Your Own Device programs and employee cell phone use present a range of employment and labour liabilities for employers: smartphones can be a real forum for employees to engage in protected concerted activities, an opportunity for unauthorized overtime work, and a tool to access inappropriate images and harass co-workers (Lies and Young, 2016). Yet, the biggest challenging effects posed by cell phones that appear from their inappropriate use are: i) distracts driving; ii) distracts operation of industrial machinery; iii) distracts employees at the workplace; iv) additional liabilities for distracting employees; v) cell phone fires and explosions (Lies and Young, 2016). 
Moreover, policy-makers in different sectors should contribute to make healthy apps on the mobile phones, in order to improve the consumer protection and safety (Parker et al., 2018). Also, the mobile phone empower employees at work and reduce transaction costs of informal business, and deeper access to resources and information from broadband can bring improvements even in personal live (Garcia-Murillo and Velez-Ospina, 2017; Garifova, 2015).

\section{BACKGROUND AND LITERATURE REVIEW}

When it comes to report the time and the duration of mobile voice calls, it seems that respondents are not too honest, and thus major discrepancies appear between what is self-reported and how their behaviour looks like (Abeele et al., 2013). The flow of information inside the organizations, that comes in touch with colleagues, managers and other stakeholders, should be within the boundary of corporate regulations (Abueed and Aga, 2019). The same authors state that into companies there are two types of information (explicit and tacit), and that, while explicit knowledge (knowledge is obviously more than simple piece of data/information) impacts innovation and financial performance (meaning the long term oriented performance), tacit knowledge influences the operational performance (meaning the short term performance) (Abueed and Aga, 2019). According to the 2017 U.S. Mobile Application Report (Figure 1), it was found that the smartphone dominates for 18-24 year-old, who spend an amazing 2/3 of their digital media time on smartphone apps alone (Comscore, 2017).

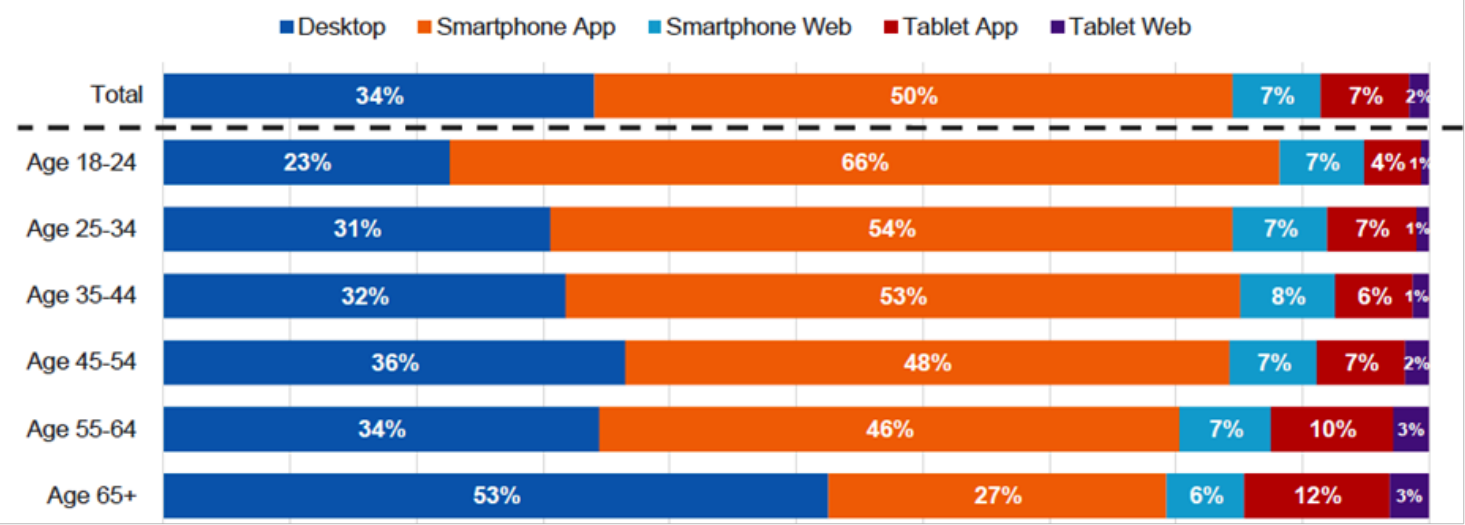

Figure 1. Share of time spent on mobile devices by age

Source: adapted from Comscore, (2017)

Despite the fact that it is reported that Social media is intensive and progressive used for sharing knowledge, there is no finality in understanding to well this direction (Ahmed et al., 2019). However, the following types of Social media are discussed: collaborative projects, blogs/microblogs, virtual communities, socializing networks and the virtual world of games (Kaplan and Haenlein, 2010). Other authors admit that socializing networks (which represent less than Social media) play a central role in diminishing the barriers in knowledge transfer and that, Social media responds well at cooperation and interconnectivity for research-development and innovation into companies (Georgescu and Popescu, 2013). In a study it was demonstrated that the urgency and the perceived dependence on the mobile phone are facets of impulsivity (Bilieux et al., 2007). Also, later, in another study, four dimensions of problematic mobile phone use aspects were discovered: prohibited use, dangerous use, dependence and financial problem (Bilieux et al., 2008). In time, negative aspects for using mobile phones at work were also argued, even for professional purposes, like addiction through leisure time (Duke and Montag, 2017). Other negative aspects 
were registered in a study with students, and it was demonstrated that their academic performances are affected, because attention is focused on other activities on the smartphones while studying. Furthermore, smartphones can be problematic for those who have constant connections, being addicted of apps combined with psychological factors (Velthoven et al., 2018). Even if there are apps to limit the mobile phone use, there are no proves that these work (Velthoven et al., 2018).

The positive effects for using mobile phones at work are synthesized, as it follows: possible better job performance, better social capital, better relationships with the colleagues, better communication, the feeling of "being together", trust and enthusiasm ( $\mathrm{Li}$ and $\mathrm{Lin}, 2019)$. If mobile phones are constantly used for working tasks, then a predisposition to the users to control and check more frequently their phone during activities appears ( $\mathrm{Li}$ and Lin, 2019). Also, using mobile technology can positively influence the explicit security knowledge of employees (Olak et al., 2019). Still, because of the communication technologies, there are people that disconnect their mobile devices at work in order to keep separate the work from non-work areas (Russo et al., 2019). However, mobile phones usage can lead to environmental, energy and health effects and it is recommended that the mobile telecommunication industry and governments should work together in order to design efficient regulations that minimize the negative effects (Manivannan, 2016).

Mobile device adoption in the workplace is not yet mature (Forni,A.A., and Van der Meulen, 2016). Although $80 \%$ of workers surveyed in a study received one or more corporate-issued devices, desktops are still the most popular corporate devices among businesses, with more than half of workers receiving corporate-issued desktop PCs (Forni,A.A., and Van der Meulen, 2016). Also, the majority of smartphones used in the workplace are personally owned devices (Forni,A.A., and Van der Meulen, 2016). The same study states that "smartphones and phablets are the most popular personally owned devices used for work, with $39 \%$ of employees using them, compared with just $10 \%$ who are only using corporate-issued smartphones and phablets” (Forni,A.A., and Van der Meulen, 2016).

Employees are more frequently conducting work in the cloud, using mobile business applications to create spreadsheets, presentations and documents. According to Stanford University, there are rules defining when using smartphones within the organization is a business necessity: i) It is vital for the mobile employee to be in constant touch with the office, lab or medical facility; ii) The employee is responsible for emergency preparedness and must be available and on-call around-the-clock for a specific business period; iii) A group of employees has the need for group or shared Equipment/Services such as rotating on-call contact; iv) The employee does not have access to a landline or other communication device when doing a substantial portion of his or her job and while communicates with the supervisor (Services, 2020).

A mobile app can be created with endless capabilities. Many business owners are developing mobile apps for their employees. For example, a former employer provided an app that enabled employees to easily access their work schedules, production data, payroll, and other relevant information that would otherwise be accessed from only one location. Employee based apps have been shown to improve employee engagement and efficiency in the workplace.

However, a company may use or not a strict policy or a flexible one for using the mobile phone at work for personal purposes (Bright HR, 2020). The strict version of the internal regulation would provide the following points of restrictions (Bright HR, 2020):

- Mobile phones are off during work hours;

- Mobile phones are off/on silent during meetings;

- Mobile phones are left in a desk drawer, coat/bag, or a company locker;

- Employees should understand that the failure to adhere to the companies' rules regarding the use of mobile phone during work could be a disciplinary offence.

The flexible policy for using mobile phones at work for personal issues would provide the following points of restrictions (Bright HR, 2020): 
- Mobile phones can be in the employee' pocket or on his/her desk;

- Mobile phones should be set to silent or vibrate mode;

- Mobile phones can be used for voice calls/ text messages in a special private area;

- Mobile phones should not be used during meetings;

- Mobile phones should be used on lunch or break for personal calls, texts, e-mails, etc. There are also a lot of functions of mobile devices that can improve communication at work, and this is useful for the organizational context (Bright HR, 2020):

- Mobile phone can be used for reminders for specific tasks, meeting, to respond to e-mails, etc.;

- Communication can be improved between members of team projects;

- Instruments such as calculator, memo, etc. can be used for working tasks.

There are many possibilities for using mobile phones in the workplace, and these can even reduce the workload. It is important to employees not to not fall into the trap of using too much social apps, or other tools (games, music), which distract them from the workplace, or which contravene to the internal rules of the companies. Even if a mobile device makes the man modern (Garifona, 2015), still we have to highlight that a balance is needed for its use. In what concerns the use of mobile phones for professional goals at work through specialized applications, there is no accent put on this, although there are voices that argue that the use of mobile phones should be regulated by a sistematic procedure (Nestian et al., 2020).

\section{METHODOLOGY}

In this paper a quantitative research was used, developed through an online questionnaire created in the Google Docs program. This instrument was pretested at the beginning of July 2018 and it was repeatedly modified, such that, between mid of July and December 2018, 368 responses were collected from different professionals from Romania.

The questionnaire was disseminated on Social networks and through e-mail, and we have managed to make the respondents curious about our research using a brief description of the study. The entire logic of the whole study is presented in the following figure 2:

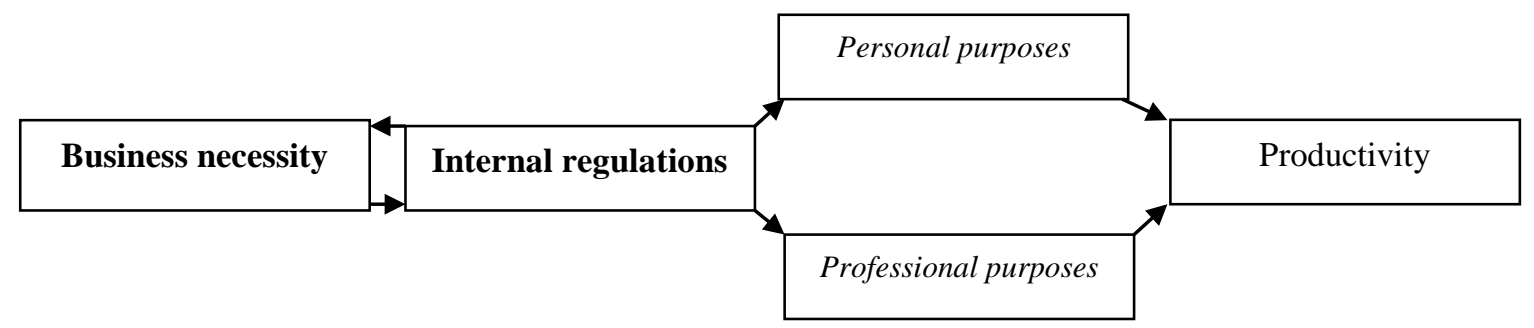

Figure 2. The whole study regarding the using of mobile phones at work Source: Own processing

The current research involves only the interactions between the need to use the mobile phones at work (business necessity), respectively, the internal regulations. The entire questionnaire has 24 questions, but in the current research only six of them were used (with multiple sub-items). The Cronbach Alpha coefficient of the entire research questionnaire has a value of 0.893 . The same coefficient, only for the sub-items used in this paper, has a value of 0.787 .

The hypotheses of the study are:

H1. There is a positive correlation between "Work requires professional communication through phone (voice calls only)" and "Phone calls can be carried out in the spaces where employees are working". 
H2. There is a positive correlation between "Work involves immediate reactivity to written messages and e-mails without accessing the computer" and "The phone is at employee during work".

H3. There is a positive correlation between "Work involves the use of social networks without accessing the computer" and "The phone is used for personal purposes during work".

H4. There is a positive correlation between "Work involves immediate reactivity to written messages and e-mails without accessing the computer" and "There is an immediate reactivity to communication for professional purposes using messaging applications”.

H5. There is a positive correlation between managers who prohibit and penalize the use of mobile phones for personal purposes at work and the fact that work involves using a fixed phone.

H6. There is a positive correlation between managers who are permissive, as long as the working tasks are fulfilled and the fact that work requires professional communication through phone (voice calls only).

\section{RESULTS}

Employees were asked if they use the fixed/mobile phone at work for personal purposes, professional ones or for both. The question was designed with multiple answers, so that the respondents had the opportunity to checkmark more options. The results obtained are in the table below.

Table 1. The way employees use at work phones for personal and professional tasks

\begin{tabular}{|l|c|c|}
\hline \multicolumn{1}{|c|}{ Ways of using fixed/mobile phone at work } & Frequency & $\begin{array}{c}\text { Percent } \\
\text { related to } \\
\text { N=368 (\%) }\end{array}$ \\
\hline $\begin{array}{l}\text { I have a fixed phone at work, which I use only for work } \\
\text { tasks }\end{array}$ & 117 & 31.79 \\
\hline $\begin{array}{l}\text { I have a fixed phone at work, which I use also for } \\
\text { personal purposes }\end{array}$ & 213 & 2.17 \\
\hline $\begin{array}{l}\text { I use my personal mobile phone for work and personal } \\
\text { purposes }\end{array}$ & 107 & 29.08 \\
\hline $\begin{array}{l}\text { I use my personal mobile phone for personal purposes } \\
\text { and I have a second mobile phone for work }\end{array}$ & 38 & 10.33 \\
\hline $\begin{array}{l}\text { I use the mobile phone provided from work for work and } \\
\text { personal purposes }\end{array}$ & & \\
\hline
\end{tabular}

Source: Own processing

The majority of respondents (213, with a percentage of 57.88\%) use their personal mobile phone for work and personal stuff. On the one hand, we consider that this is a benefit for the company in terms of costs, as any costs for mobile phones and the related subscriptions are eliminated. On the other hand, the biggest problem about this statement is the secrecy of information from work. This problem appears because, when using information related to working tasks on personal mobile phone (through messages, e-mails, voice calls, etc.), companies have no control over this. At the opposite, only 8 respondents (2.17\%) answered that they use the fixed telephone at work for personal problems. We consider that it is natural to have such a situation, as long as today the mobile phones and subscriptions are at low prices, and thus, almost anyone can afford them. Interestingly is that, 117 respondents (31.79\%) answered that they use the fixed phone only for working tasks. Taking into account the voice calls made at work, the fixed phone represent the best 
solution to keep the working tasks secretly. However, this solution is not applicable for any type of work.

Given that not all work tasks involve the use of the phones, respondents were asked to tick to what extent their work involve the use of a fixed/mobile phone. The answers were given on a scale from 1 (minimum) to 5 (maximum), and are presented in the table 2.

Table 2. Respondents' working tasks $(\mathrm{N}=368)$

\begin{tabular}{|l|c|c|}
\hline \multicolumn{1}{|c|}{ What the work involves (Business necessity) } & Mean & $\begin{array}{c}\text { Std. } \\
\text { Deviation }\end{array}$ \\
\hline \multicolumn{1}{|c|}{ Work involves using a fixed phone } & 2.38 & 1.37 \\
\hline $\begin{array}{l}\text { Work requires professional communication through phone (voice } \\
\text { calls only) }\end{array}$ & 3.48 & 1.33 \\
\hline $\begin{array}{l}\text { Work involves professional communication through video or audio } \\
\text { calls using the computer }\end{array}$ & 2.26 & 1.27 \\
\hline $\begin{array}{l}\text { Work involves professional communication through video calls } \\
\text { using the mobile phone }\end{array}$ & 1.65 & 0.99 \\
\hline $\begin{array}{l}\text { Work involves immediate reactivity to written messages and e- } \\
\text { mails without accessing the computer }\end{array}$ & 2.75 & 1.46 \\
\hline $\begin{array}{l}\text { Work involves the use of social networks without accessing the } \\
\text { computer }\end{array}$ & 2.16 & 1.33 \\
\hline $\begin{array}{l}\text { Work involves quick search of information on the Internet without } \\
\text { accessing the computer }\end{array}$ & 2.74 & 1.43 \\
\hline $\begin{array}{l}\text { Work involves the use of professional applications installed on the } \\
\text { mobile phone }\end{array}$ & 2.44 & 1.39 \\
\hline $\begin{array}{l}\text { Work involves commercial relationships through on-line platforms } \\
\text { without accessing the computer }\end{array}$ & 1.93 & 1.19 \\
\hline $\begin{array}{l}\text { Work involves the use of orientation applications (Maps, GPS, } \\
\text { Waze, etc.) for travel }\end{array}$ & 2.31 & 1.42 \\
\hline $\begin{array}{l}\text { Work involves obtaining evidence of the activity through audio- } \\
\text { video recordings }\end{array}$ & 1.68 & 1.12 \\
\hline
\end{tabular}

Source: Own processing

The highest average (3.48) was recorded for "Work requires professional communication through phone (voice calls only)". On the second place is "Work involves immediate reactivity to written messages and e-mails without accessing the computer" (with an average of 2.75), and on thirdly place is "Work involves quick search of information on the Internet without accessing the computer" (with an average of 2.74). The lowest scores were recorded for "Work involves professional communication through video calls using the mobile phone" (with an average of 1.65) and "Work involves obtaining evidence of the activity through audio-video recordings" (with an average of 1.68).

Basically, most of the working tasks for the respondents within the sample depend on voice communication on the phone. There is a tendency to decrease the dependency of the work to the computer, and to replace its functions by the mobile phone ("Work involves immediate reactivity to written messages and e-mails without accessing the computer" with an average of 2.75; "Work involves the use of social networks without accessing the computer" with an average of 2.16; "Work involves quick search of information on the Internet without accessing the computer" with an average of 2.74; "Work involves the use of professional applications installed on the mobile 
phone" with an average of 2.44; "Work involves the use of orientation applications (Maps, GPS, Waze, etc.) for travel" with an average of 2.31).

Messages and information searches on the Internet are available to any employee, and denotes promptness and flexibility in the work. Respondents declare that video calls through the mobile phone does not predominate in their work, while data indicates a higher use of video calls using the computer (with an average of 2.26). Also, the audio-video recordings for the performed activity are not predominant in the work tasks.

Employees that have participated in the study were asked whether employers should restrict or not the use of mobile phones for personal purposes during the work schedule. The options for answering at this question were "Yes", "No", respectively "I don't know". The results are shown in the table 3 .

Table 3. Employees' opinions on restricting the use of mobile phones at work for personal purposes $(\mathrm{N}=368)$

\begin{tabular}{|c|c|c|}
\hline $\begin{array}{c}\text { Should the employer restrict the use of the } \\
\text { mobile phone at workplace for personal } \\
\text { purposes? }\end{array}$ & Frequency & $\begin{array}{c}\text { Percent } \\
\text { (\%) }\end{array}$ \\
\hline Yes & 28 & 7.61 \\
\hline No & 315 & 85.60 \\
\hline I don't know & 25 & 6.79 \\
\hline
\end{tabular}

Source: Own processing

315 respondents (85.60\%) are of the opinion that the use of the mobile phone for personal purposes in the workplace should not be restricted, 25 of them $(6.79 \%)$ say that they do not know if the answer should be "Yes" or "No", and 28 of them (7.61\%) think that the use of mobile phones at work for personal issues it should be restricted. Moreover, this question was followed (only for the people who answered "Yes" in the questionnaire for the previous data) by another open question in which, the respondents could write the way it should be restricted the use of the mobile phone for personal problems at work. The ideas of the respondents are presented below, without any order of importance:

- The employer should allow the employee to use the mobile phone only during the lunch break /or other breaks;

- The phone could only be used at certain intervals of time;

- The working time program should be reduced from 8 to 6 hours so that the employees could compress the work and stop using the mobile phone to fill the time when they do not actually work;

- Some interdictions should be introduced for the use of the mobile phone during the work program (except for urgent cases) in the internal regulations of the company/or in the individual employment contract;

- Applications should be installed on the mobile devices to monitor the time spent on the phones and, if possible, to check the time spent on each application;

- Time limits for using mobile phones should be communicated and agreed with the employee in advance;

- At the beginning of the work program, the employee should leave the phone on the boss's office/in the locker/or in a special place and take it away only for urgent matters;

- Access to social networks/games on mobile phones should be limited;

- Penalties should be applied in cases in which employees use excessive the mobile phones for personal interests;

- Employees should be monitored through the camera;

- Awareness and accountability of the personnel should be realized regarding the use of the mobile phones for personal purposes. 
Each of the respondents who gave their opinion regarding restricting the use of the mobile phone at work, have their own, original vision about these possible actions. Possible restrictions vary, from the most permissive ones (communication and approval of the rules with employees in advance), to the most restrictive ones (prohibitions in the internal regulation of the company/or in the individual employment contract).

In order to complete the vision about the attitude of the employees and the rules of the companies regarding the use of the mobile phone for personal purposes during the working program, in the research questionnaire we included a question regarding the attitudes and reactions of the managers about this aspect. The answers were given on a scale from 1 (minimum) to 5 (maximum), and the results are illustrated in the table 4.

Table 4. Managers' behaviors regarding the use of mobile phones during work for personal purposes $(\mathrm{N}=368)$

\begin{tabular}{|l|c|c|}
\hline $\begin{array}{c}\text { Managers' behaviors regarding the use of mobile phones for } \\
\text { personal purposes during work }\end{array}$ & Mean & $\begin{array}{c}\text { Std. } \\
\text { Deviation }\end{array}$ \\
\hline They prohibit and penalize this type of behaviour & 1.71 & 1.02 \\
\hline They make observations to those who do so & 2.07 & 1.18 \\
\hline They prohibit and penalize this type of behaviour & 2.52 & 1.26 \\
\hline They are completely indifferent to this behaviour & 2.71 & 1.42 \\
\hline $\begin{array}{l}\text { They also use the mobile phone for personal problems during } \\
\text { work }\end{array}$ & 3.89 & 1.05 \\
\hline They are permissive, as long as you fulfil your work tasks & 4.11 & 1.09 \\
\hline $\begin{array}{l}\text { They always analyze how much time employees spent on the } \\
\text { phone for personal purposes }\end{array}$ & 1.93 & 1.06 \\
\hline $\begin{array}{l}\text { They notify in meetings that too much time is spend on the } \\
\text { phone for personal reasons, but without mentioning the names } \\
\text { of the colleagues }\end{array}$ & 1.97 & 1.26 \\
\hline
\end{tabular}

Source: Own processing

The highest average (4.11 out of 5) was recorded for the item "They are permissive, as long as you fulfil your work tasks". On the second place it was found that the managers also use mobile phones for personal problems during work (with an average of 3.89 out of 5), and on thirdly place it was found that managers are completely indifferent to this behaviour of the employees (with an average of 2.71 out of 5). 5). The lowest score was registered for the prohibition and penalization of using the mobile phone for personal purposes at the workplace (with an average of 1.71 out of 5).

Concretely, the results indicate that the managers of the respondents in the questionnaire are quite open about the use of mobile phones for personal purposes in the workplace, but that this behaviour should not influence the results of the work in any negative way. As long as managers use mobile phones for this personal purposes, the employees do the same. Moreover, it is noted that, there is a low tendency to prohibit and penalize this type of behaviour, which induces a state of relaxation and goodwill for balancing personal with professional life at work.

Employees were also asked to what extent they have rules for using the mobile phones for personal purposes in the workplace. The answers were given on ratings from 1 (minimum) to 5 (maximum), and the results are illustrated in the table 5. 
Table 5. Internal regulation regarding the use of mobile phone at work $(\mathrm{N}=368)$

\begin{tabular}{|l|c|c|}
\hline \multicolumn{1}{|c|}{ Internal rules } & Mean & $\begin{array}{c}\text { Std. } \\
\text { Deviation }\end{array}$ \\
\hline The phone is at employee during work & 3.98 & 1.10 \\
\hline The phone is used for professional purposes during work & 3.96 & 1.09 \\
\hline The phone is used for personal purposes during work & 3.54 & 1.11 \\
\hline The phone can be used for personal purposes only during breaks & 3.76 & 1.04 \\
\hline The phone can be kept in the field of vision when working & 3.78 & 0.98 \\
\hline The phone is held on silent mode when working & 3.67 & 1.03 \\
\hline $\begin{array}{l}\text { The setting on silent mode of the phone is done only during } \\
\text { meetings }\end{array}$ & 3.55 & 1.08 \\
\hline $\begin{array}{l}\text { Phone calls can be carried out in the spaces where employees are } \\
\text { working }\end{array}$ & 3.44 & 1.22 \\
\hline It can be answered at any time at calls during working hours & 3.54 & 1.18 \\
\hline It can be answered at any time at calls during breaks & 3.47 & 1.17 \\
\hline $\begin{array}{l}\text { There is an immediate reactivity to communication for professional } \\
\text { purposes using messaging applications }\end{array}$ & 3.47 & 1.03 \\
\hline
\end{tabular}

Source: Own processing

Mobile phones are at employees during work (the item has an average of 3.95 out of 5), are used for professional purposes (with an average of 3.96 out of 5), and can be kept in the visual field (with an average of 3.78 out of 5). The lowest score from all the rules was registered for the calls which can be carried out in the spaces where the other colleagues work (with an average of 3.44 out of 5). And yet, there are no major differences between the maximum and minimum score of the items (3.98 $3.44=0.54$ ), which indicates that there is a balance between using the mobile phone as needed (for personal or professional purposes), and between not to use it during meetings, in front of other colleagues (in order not to disturb their activity), etc. At the same time, the mobile phone can be used both during work and during breaks. It remains up to each employee when and how much it is used, and for what purposes.

What is interesting and yet contradictory, is the fact that the average for "The phone can be used for personal purposes during work" is 3.54, while the mean for "The phone can be used for personal purposes only during breaks" is higher, of 3.76. It is possible that the respondents did not focus on that "only" term from the fourth item, and thus, evaluating just that the mobile phone can be used at work during breaks. After all, it is natural to the employer to not put any restrictions on breaks during work, meaning that the employee is free to do what he wants to relax in his free time.

The employees were given the opportunity to frame the possibility of answering or not at mobile phone calls during the work program in explicit acceptance by their organization (by regulations), respectively by tacit acceptance (without written rules). The respondents had only one possible option to answer. The results are shown in the table 6. 
Table 6. The possibility to answer at phone calls during work at any moment $(\mathrm{N}=368)$

\begin{tabular}{|l|c|c|}
\hline It can be answered at any time at calls during work & $\begin{array}{c}\text { Frequen } \\
\text { cy }\end{array}$ & $\begin{array}{c}\text { Percent } \\
\text { (\%) }\end{array}$ \\
\hline Prohibited by regulation & 35 & 9.51 \\
\hline Tacitly prohibited & 42 & 11.41 \\
\hline I don't know & 44 & 11.96 \\
\hline Tacitly allowed & 183 & 49.73 \\
\hline Allowed by regulation & 64 & 17.39 \\
\hline
\end{tabular}

Source: Own processing

As it can be seen, the most frequent responses regarding the possibility of "answering mobile phone calls anytime at work" are that this is "Tacitly allowed" (183 respondents checked this option, with a percentage of $49.73 \%$ ). In the second place is the possibility to answer to calls anytime during work, with written agreement in the regulation (64 employees put this option, with a percentage of $17.39 \%)$. The smallest percentage belongs to the option of prohibiting in the regulation to answer at calls during the work program (35 replies, with a percentage of 9.51\%).

Therefore, for the considered sample, so far no emphasis is placed on explicit permissions (internal regulations, clauses in individual labour contracts, etc.) in order to be able to answer at calls during work. However, if this is allowed tacitly, this does not mean that employees have to make abuse with their personal phone calls. Figure 3 shows four quadrants for types of regulation in organizations for using mobile phones at work, considering the following variables: the permission to use the mobile phone in the workplace (allowed-prohibited) and the way in which this behaviour is accepted or prohibited (explicit-tacit).

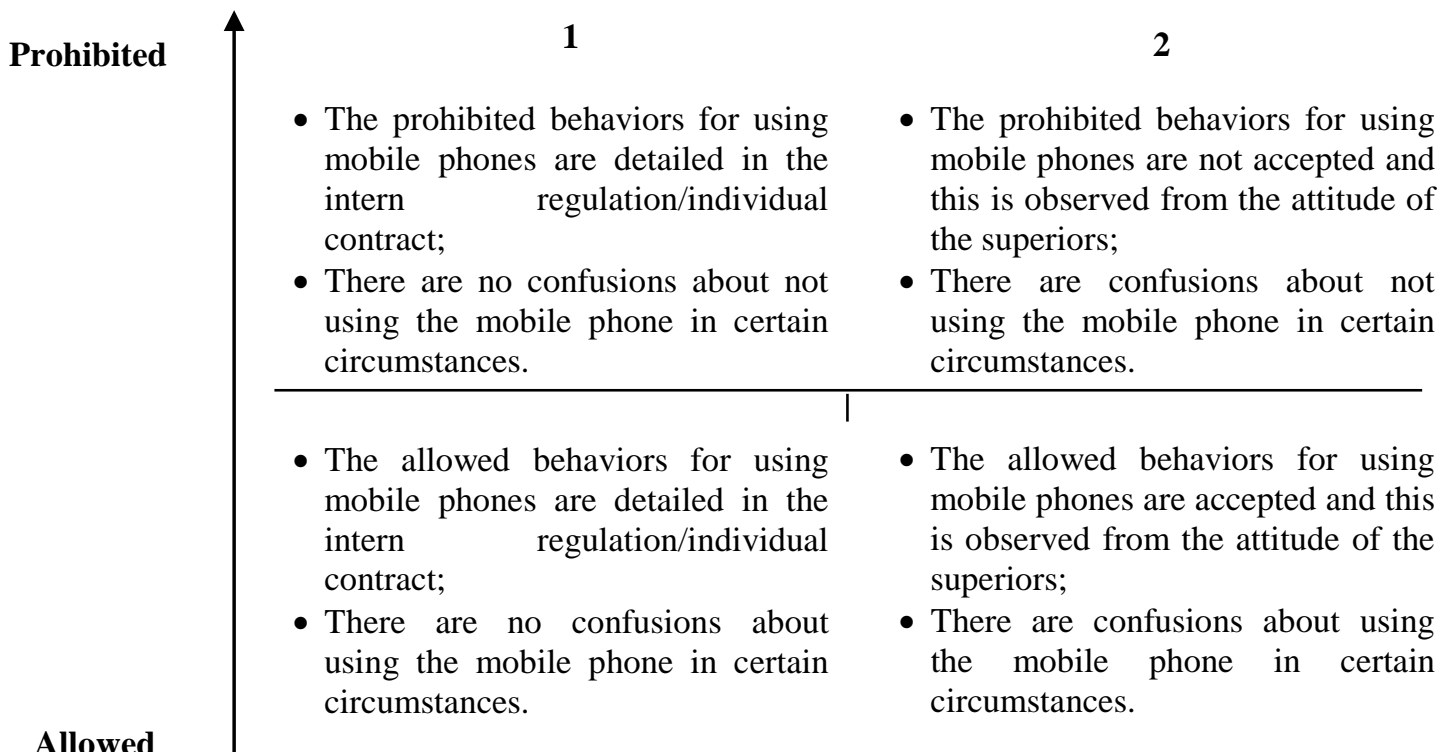

Explicit (Regulation)

Tacit (No regulation)

Figure 3. Types of regulation in organizations for using movıe pıuıe dt work Source: Own processing

The figure above indicates four possible frameworks in which organizations can fit in, given the existence of regulations for the use of the mobile phone, respectively the acceptance or prohibition of its use during work. For these categories, it is not specified whether the use of the mobile phone should be carried out for personal or professional purposes. The most trenchant dial is the first one, 
in which the prohibition of the use of the mobile phone is vehement: there are rules and this behavior is clearly forbidden.

The most permissive dial is the fourth, in which the mobile phone can be used at any time, and this should be written in the regulation. Still, we consider that employers do not necessarily want to express this permission into documents, so that, probably, the third quadrant is the most realistic for our research (fact suggested also by the statistics from the previous table).

\subsection{Testing the hypotheses}

Since the distribution for the considered sample is not a normal one, data was used for the correlation analysis with the coefficient Spearman for nonparametric data. The results for testing the hypothesis are illustrated in the following table.

Table 7. Testing the hypotheses $(\mathrm{N}=368)$

\begin{tabular}{|c|c|c|c|c|}
\hline Hypothesis & p values & $\begin{array}{c}\text { Spearman } \\
\text { coefficient }\end{array}$ & Type of correlation & $\begin{array}{c}\text { Hypothesis } \\
\text { testing }\end{array}$ \\
\hline H1 & $0.000 *$ & 0.241 & $\begin{array}{c}\text { Weak, positive } \\
\text { correlation }\end{array}$ & H1 accepted \\
\hline H2 & $0.000 *$ & 0.215 & $\begin{array}{c}\text { Weak, positive } \\
\text { correlation }\end{array}$ & H2 accepted \\
\hline H3 & $0.001 *$ & 0.171 & $\begin{array}{c}\text { Very weak, positive } \\
\text { correlation }\end{array}$ & H3 accepted \\
\hline H4 & $0.000 *$ & 0.269 & $\begin{array}{c}\text { Weak, positive } \\
\text { correlation }\end{array}$ & H4 accepted \\
\hline H5 & $0.027 * *$ & 0.116 & $\begin{array}{c}\text { Very weak, positive } \\
\text { correlation }\end{array}$ & H5 accepted \\
\hline H6 & 0.179 & 0.070 & H6 rejected \\
\hline & \multirow{2}{*}{ * Correlation is significant at the 0.01 level (2-tailed). } & \\
\hline
\end{tabular}

Source: Own processing

Considering the interval $\pm(0,00-0,19]$ for very weak correlation and $\pm[0,20-0,39]$ for weak correlation, only the first five hypotheses were accepted. Since p value for the sixth hypothesis is greater than 0.05 , this hypothesis is rejected. First four hypotheses are formulated using correlations between what work involves (Table 2) and internal rules from work (Table 5). The last two hypotheses follow correlations about Managers' behaviours regarding the use of mobile phones for personal purposes during work (Table 4) and what work involves (Table 2). All the hypotheses are accepted, excepting H6, which indicates no correlation between managers who are permissive to use mobile phone at work for personal purposes, as long as the working tasks are fulfilled and the fact that work requires professional communication through phone (voice calls only).

\section{DISCUSSION OF FINDINGS}

The general picture about the connections between the business necessity and the internal regulation about the use of mobile phones at work, resulted from our research, depicts a permissive environment created by the managers. First of all, we have seen that the majority of respondents (57.88\% of the respondents) declare that they use their personal mobile phone for work and personal stuff. This permissive environment translates into the expectation that the use of mobile phones at work should not be restricted. $85.60 \%$ of the respondents share the opinion that the use of the mobile phone for personal purposes in the workplace should not be restricted, while only $7.61 \%$ of them think the opposite. Also, almost half of the respondents are assuming the possibility of 
answering mobile phone calls anytime at work considering that this is "Tacitly allowed" (49.73\% of the respondents). Between the managers' behaviors, the lowest score was registered for the prohibition and penalization of using the mobile phone for personal purposes at the workplace (with an average of 1.71 out of 5 ).

The behavior of managers was described mostly as permissive ("They are permissive, as long as you fulfil your work tasks", with the highest average - 4.11 out of 5), setting the example ("The managers also use mobile phones for personal problems during work", with an average of 3.89 out of 5) or being completely indifferent to this behavior of the employees (with an average of 2.71 out of 5). The results indicate that the managers are quite open about the use of mobile phones for personal purposes in the workplace, but that this behavior should not influence the results of the work in any negative way. As long as managers use mobile phones for personal purposes, the employees do the same. Moreover, there is a low tendency to prohibit and penalize this type of behavior, which induces a state of relaxation and goodwill for balancing personal with professional life at work.

The same permissive attitude is described in the behavioral rules specified by the respondents. The rules mostly specified by the respondents are that mobile phones are at employees during work (the item has the average of 3.95 out of 5), the mobile phones are used for professional purposes (with an average of 3.96 out of 5), and they can be kept in the visual field (with an average of 3.78 out of 5). To this we can add the fact that the lowest score from all the rules was registered for carrying calls in the spaces where the other colleagues work (with an average of 3.44 out of 5), showing that this is rarely a rule in place. The results indicates that there is a balance between using the mobile phone as needed (for personal or professional purposes), between using or not using it during meetings or in front of other colleagues (in order not to disturb their activity), between using it during work and during breaks.

The testing of the six hypotheses contributes to the same image. The first four hypotheses were formulated using correlations between variables describing what work involves (business necessity) and the variables describing internal rules for using the mobile phones at work (regulation). The last two hypotheses are searching correlations about Managers' behaviors regarding the use of mobile phones for personal purposes during work and what work involves (business necessity). Only the first five hypotheses were accepted, with weak or very weak correlations. This shows that generally, business necessity is weakly correlated with the regulation of using mobile phones at work, and that the managers' behavior is not correlated or is weakly correlated with the business necessity to use the mobile phone at work.

Two other interesting results are linked with the use of technology at work. First, we find out that most of the working tasks for the respondents within the sample require voice communication on the phone (with an average of 3.48 out of 5). The second result is revealing the tendency to decrease the dependency of the work on the computer, and to replace its functions by using the mobile phone at work for immediate reactivity to written messages and e-mails, for accessing social networks, for quick search of information on the Internet, for professional applications and for orientation applications (Maps, GPS, Waze, etc.) for travel. All these functions had an average above 2 on a scale from 1 to 5, revealing their emergence in replacing the similar computer functions.

\section{CONCLUSIONS, LIMITS AND IMPLICATIONS FOR RESEARCH/PRACTICE}

The main conclusion of this study is that the employees perceive a permissive environment created by the managers about the use of mobile phones at work. This finding is supported by the weak or very weak positive correlations between variables describing the business necessity for using the mobile phone at work and the existence of an internal regulation about it. This finding is also supported by the lack of correlation or the weak correlation between the business necessity and the behavior of managers about the use of mobile phones at work for personal or professional purposes. 
For practitioners, one conclusion is that the best conduct of managers in response to the business necessity and the employees work-life balance needs is to tacitly allow the uses of the mobile phones in ways that are potentially beneficial for the business or for the work-life balance of the individuals. This tacit allowance of the use of mobile phones at work, for both personal and professional purposes, comprises a relaxed regulatory framework and a relaxed behavioural response from the managers, supported by the understanding of the fact that most of the today's jobs require the use of a mobile phone for multiple professional purposes, such as phone calls, immediate reactivity to written messages and e-mails, accessing social networks, quick search of information on the Internet, professional applications and orientation applications.

Another practical conclusion is that the mobility provided by the mobile phone, together with their computer like functions, makes them a better option that a classic computer or even a laptop as work instruments, in a significant number of cases.

The limits of our study are synthesized, as it follows: the sample has no representativeness for the industries in which the respondents activate, we did not collected data directly from the organizational context in order to compare the respondents' declarations with internal regulation on mobile phones usage, and also the employees' opinions about their managers who can tacitly prohibit/allow the use of mobile devices at work for personal purposes are certainly subjective. Another limitation of the study consists in the fact that, in the literature there are only a few information regarding the extent to which work tasks involve the use of mobile devices, and because of this fact, this paper has analyzed only practical example of regulation that companies are using and legislative/institutional paths that cover some aspects for using mobile phones during work.

\section{REFERENCES}

Abeele, M., V., Beullens, K. \& Roe, K. (2013). Measuring mobile phone use: Gender, age and real usage level in relation to the accuracy and validity of self-reported mobile phone use. Mobile Media \& Communication, 1(2), 213-236. doi: 10.1177/2050157913477095.

Abueed, R., A. \& Aga, M. (2019). Sustainable Knowledge Creation and Corporate Outcomes: Does Corporate Data Governance Matter? Sustainability, 11(20), 5575. doi: 10.3390/su11205575.

Ahmed, Y., A., Ahmad, M., N., Ahmad, N. \& Zakaria, N., H. (2019). Social media for knowledgesharing: A systematic literature review. Telematics and Informatics, 37, 72-112. doi: 10.1016/j.tele.2018.01.015.

Billieux, J., Linden, M., V., D. \& Rochat, L. (2008). The role of impulsivity in actual and problematic use of the mobile phone. Applied Cognitive Psychology, 22(9), 1195-1210. doi: 10.1002/acp.1429.

Billieux, J., Linden, M., V., D., Dacremont, M., Ceschi, G. \& Zermatten, A. (2007). Does impulsivity relate to perceived dependence on and actual use of the mobile phone? Applied Cognitive Psychology, 21(4), 527-537. doi: 10.1002/acp.1289.

Bright HR. (n.d.). In Mobile Phone Policy at Work. Retrieved February 10, 2020, from https://www.brighthr.com/articles/employee-conduct/mobile-phone-policy.

Colbert, A., Yee, N. \& George, G. (2016). The Digital Workforce and the Workplace of the Future. Academy of Management Journal, 59(3), 731-739. doi: 10.5465/amj.2016.4003.

Duke, É. \& Montag, C. (2017). Smartphone addiction, daily interruptions and self-reported productivity. Addictive Behaviors Reports, 6, 90-95. doi: 10.1016/j.abrep.2017.07.002.

European Commission.(2017). Opinion 2/2017 on data processing at work. Retrieved February 18, 2020 from file:///C:/Users/User/Downloads/Opinion22017ondataprocessingatwork-wp249.pdf

Forni,A.A., \&Van der Meulen, R.(in press). Gartner Survey Shows That Mobile Device Adoption in the Workplace Is Not Yet Mature. Press Releases.

Garcia-Murillo, M. \& Velez-Ospina, J., A. (2017). ICTs and the informal economy: mobile and broadband roles. Digital Policy, Regulation and Governance, 19(1), 58-76. doi: 10.1108/dprg-022016-0004. 
Garifova, L. (2015). Infonomics and the value of information in the digital economy. Procedia Economics and Finance, 23, 738-743. doi: 10.1016/s2212-5671(15)00423-2.

Georgescu, M. \& Popescu, D. (2015). Social media - the new paradigm of collaboration and communication for business environment. Procedia Economics and Finance, 20, 277-282. doi: 10.1016/s2212-5671(15)00075-1.

Kaplan, A., M. \& Haenlein, M. (2010). Users of the world, unite! The challenges and opportunities of Social Media. Business Horizons, 53(1), 59-68. doi: 10.1016/j.bushor.2009.09.003.

Li, L. \& Lin, T. T. C. (2019). International Journal of Qualitative Methods, 18, 1-12. doi: $10.1177 / 1609406918822240$.

Lies, M.A.,Young, A.R. (2016, October).Cell Phones at the workplace: protecting employee safety. Seyfarth. Retrieved September 20, 2020, from https://www.laborandemploymen tlawcounsel.com/2016/10/cell-phones-at-the-workplace-protecting-employee-safety/

Londhe, B., Radhakrishnan, S. \& Divekar, B., R. (2014). Socio economic impact of mobile phones on the bottom of pyramid population- a pilot study. Procedia Economics and Finance, 11, 620-625. doi: 10.1016/s2212-5671(14)00227-5.

Manivannan, S., V. (2016). Environmental and health aspects of mobile phone production and use: Suggestions for innovation and policy. Environmental Innovation and Societal Transitions, 21, 6979. doi: 10.1016/j.eist.2016.04.002.

Mobile devices in the workplace: Are they a help or a hazard?.(n.d.) In IHSA.ca Magazine. Retrieved February 18, 2020 from https://www.ihsa.ca/pdfs/magazine/volume 14 Issue 3/mo bile-devicesin-the-workplace.pdf.

National Labor Relations Board.(n.d.).Board Decissions. Retrieved February 18, 2020 from www.nlrb.gov.

Neștian, Ș., A., Tiță, S., M. \& Turnea, E., S. (2020). Using Mobile Phones at Work in Personal and Professional Information Processes. Sustainability, 12(3), 965. doi: 10.3390/su12030965.

Olak, A., J., Hejduk, I., Karwowski, W., Tomczyk, P., Fazlagić, J., Gac, P. \& Alrehaili, O., A. (2019). The relationships between the use of smart mobile technology, safety knowledge and propensity to follow safe practices at work. International Journal of Occupational Safety and Ergonomics, 1-10. doi: 10.1080/10803548.2019.1658398.

Parker, L., Bero, L., Gillies, D., Raven, M. \& Grundy, Q. (2018). The "Hot Potato" of mental health app regulation: a critical case study of the Australian policy arena. International Journal of Health Policy and Management, 8(3), 168-176. doi: 10.15171/ijhpm.2018.117.

Provision of Mobile Equipment and Related Services. (n.d.).In Services. Retrieved February 18, 2020, from https://adminguide.stanford.edu/chapter-8/subchapter-1/policy-8-1-3.

Pryzbylski, D.J.(2019). Can you prohibit employees from using cell phones at work?. The National Law Review, IX(79). Retrieved September 10, 2020, from https://www.natlawreview.com/article/canyou-prohibit-employees-using-cell-phones-work.

Russo, M., Ollier-Malaterre, A. \& Morandin, G. (2019). Breaking out from constant connectivity: Agentic regulation of smartphone use. Computers in Human Behavior, 98, 11-19. doi: 10.1016/j.chb.2019.03.038.

Stevens,Y., Bronowicka, J. (2016). Workplace Surveillance: is our Privacy Protected at Work?. Retrieved September 10, 2020, from https://cihr.eu/workplace-surveillance-is-our-privacyprotected-at-work/

The 2017 U.S. Mobile Application Report (n.d.). In Comscore. Retrieved February 18, 2020 from https://www.comscore.com/layout/set/popup/Request/Presentations/2017/The-2017-US-MobileApp Report? $\operatorname{logo}=0 \& c=12$ ?utm_campaign $=\& u t m \_m e d i u m=e m a i l \& u t m \_s o u r c e=c o m$ score_elq_OCT2018_OPTIN_CONFIRMATION_CONTENT_ALL_AR.

Velthoven, M., H., V., Powell, J. \& Powell, G. (2018). Problematic smartphone use: Digital approaches to an emerging public health problem. Digital Health, 4, 1-9. doi: 10.1177/2055207618759167. 